\title{
Study on the Need for Postoperative Analgesic Medication in Patients where Polypropylene Mesh was Used in the Surgical Treatment of Incisional Hernias
}

\author{
IOANA HALMACIU1,2, BOGDAN ANDREI SUCIU1*, CRISTIAN TRAMBITAS ${ }^{1}$, VLAD VUNVULEA ${ }^{1}$, ALEXANDRA MARTIN STOICA ${ }^{2}$, \\ DUMITRU GODJ A ${ }^{3}$, DECEBAL FODOR ${ }^{1}$, KLARA BRINZANIUC ${ }^{1}$, CALIN MOLNAR ${ }^{3}$ \\ ${ }^{1}$ University of Medicine and Pharmacy, Department of Anatomy, 38 Gheorghe Marinescu Str., 540142, Tirgu Mures, Romania \\ ${ }^{2}$ County Emergency Clinical Hospital, Department of Radiology, 50 Gheorghe Marinescu Str., 540136, Tirgu Mures, Romania \\ ${ }^{3}$ County Emergency Clinical Hospital, Department of Surgery no. 1, 50 Gheorghe Marinescu Str., 540136, Tirgu Mures, Romania
}

\begin{abstract}
One of the most common postoperative complications that may occur in patients treated for incisional hernias is pain. The occurrence of postoperative pain refractory to drug treatment may worsen the prognosis of these patients. We have carried out a retrospective observational study in which we have introduced 122 patients operated for incisional hernia at the Surgical Clinic No. 1 in the Tirgu Mures Emergency County Clinical Hospital. The patients included in the study were divided into two groups: group A consisting of 80 patients where the polypropylene mesh was used over the aponeurosis in the surgical treatment of the incisional hernias, and the group B consisting of 42 patients where no prosthetic materials were used in the surgical treatment of the incisional hernias. All patients were administrated $1 \mathrm{~g}$ of sodium metamizole monohydrate for the treatment of pain. The statistical analysis of the data revealed that, on the day of surgery, on the first, second and third postoperative day there were statistically significant differences in the need for analgesic medication between the two groups, the need for the analgesic medication being lower for group A. In contrast, on the 4th postoperative day there were no statistically significant differences in the need for analgesic medication between the two groups. In conclusion, our study showed that, when using the polypropylene mesh in the surgical treatment of incisional hernias, the need for analgesic medication is lower in the immediate postoperative period compared to cases where surgical meshes are not used in the surgical treatment of these patients.
\end{abstract}

Keywords: analgesia, incisional hernias, mesh

Incisional hernias are quite common disorders nowadays in the general surgery clinics. It is currently thought that approximately $3-20 \%$ of patients who had a history of abdominal surgery will experience an incisional hernia over time. It has been found that the incidence of this disease is higher in smoker, diabetic, obese patients or if the patient has a history of abdominal wall infections. $[1,2]$ Although surgical treatment of incisional hernias is currently practiced extensively in many surgical centers, these surgeries are often not mild surgical interventions, with some cases of quite significant postoperative complications. One of the most common postoperative complications that may occur in these patients is postoperative pain. In the postoperative period, the incidence of postoperative pain is rather high and unfortunately many patients experience chronic pain in such cases. [3,4]

In order to reduce postoperative morbidity in these patients, many authors recommend a laparoscopic approach, which has the advantage of lower postoperative morbidity, a decrease in postoperative pain levels, shortening the period of hospitalization, and a faster social reintegration of these patients. The major disadvantage of this surgical technique is given by the high cost of the materials used, which is why this surgical technique is not yet widely practiced in Romania.

\section{Experimental part}

The purpose of this study was to evaluate the need for analgesic medication in patients operated for incisional hernias using the open, classic approach. We also tried to make a comparative study between the need for analgesic medication in the patients where mesh was used in the surgical treatment of the incisional hernia, compared to those where no mesh was used. For this purpose, we performed a retrospective observational study over a period of 1 year in which we introduced 122 patients operated with the diagnosis of incisional hernia in the Surgery Clinic no. 1 of the Emergency County Clinical Hospital Tirgu Mures.

The 122 patients included in the study were divided into 2 groups: group A was formed out of 80 patients where the abdominal wall reconstruction was done using polypropylene mesh over the aponeurosis $(65.57 \%$ of the cases - fig. 1) and B group consisting of 42 patients where the abdominal wall reconstruction was practiced without any prosthetic material (34.42\% of cases). It should be noted that, in order to obtain a statistical analysis as close as possible to the truth, we excluded from the study the patients who have undergone other types of surgical maneuvers except those related to the abdominal wall.

Only patients who were administrated a single type of analgesic medication were included in the study to rule out false positives or false negative results due to the combination of different analgesic drugs. Thus, only Algocalmin ${ }^{\mathrm{TM}}(2 \mathrm{~mL}$ ampoules containing $1 \mathrm{~g}$ sodium metamizole monohydrate) was used as analgesic medication in all patients included in the study. Analgesic medication was given as an injection, either intramuscularly or intravenously. It should also be noted that the analgesic medication was not routinely administered, but only at the patient's request. 
Fig. 1. Placing the polypropylene mesh over the aponeurosis

The data required for this study was obtained from the patients observation sheets as well as from the hospital's integrated computer network. All the data used was entered into a Microsoft Excel file. For statistical analysis we used the GraphPad software, considering that the differences between the two lots are statistically significant if the $p$ value is less than 0.05 .

\section{Results and discussions}

With the help of the statistical analysis, we tried to study separately the need for analgesic medication within each lot on day 0 (day of surgery) on the first postoperative day, on the 2 nd postoperative day, on the 3 rd postoperative day and on the 4th postoperative day. For group $A$, the results are shown in figure 2 , and in the case of group $B$, the results are shown in figure 3 . The results were expressed in grams of sodium metamizole which were administered to the patients.

The statistical analysis of the need for analgesic medication on the day of surgery showed a statistically significant difference between the two groups $(p=0.0001)$, the need for analgesic medication being low er for group $A$ (mean of $1.313 \mathrm{~g}$ ) compared to group B (average of 1.714). The need for analgesic medication was lower on the day
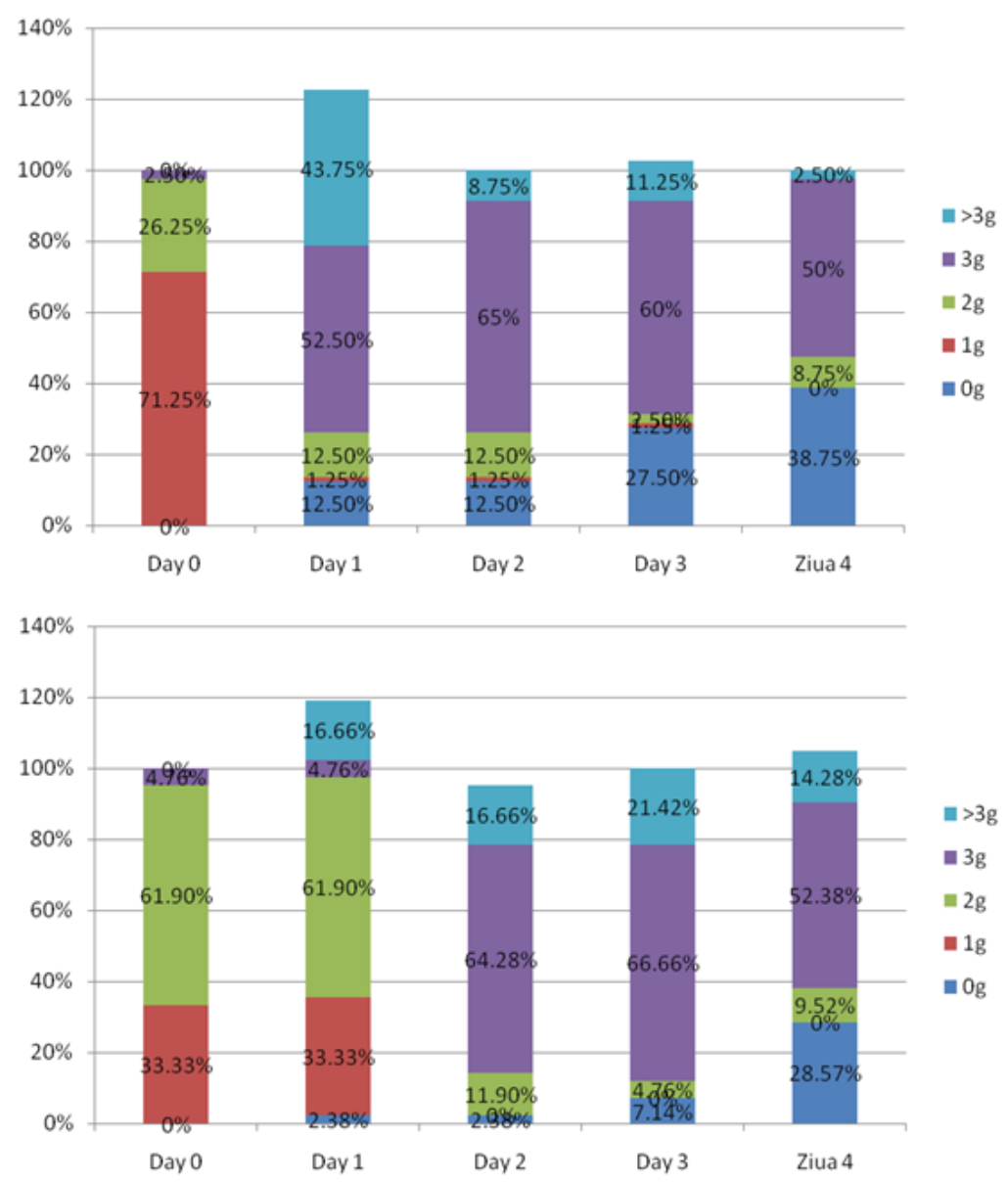

Fig. 2. The need for analgesic medication in group $A$

\begin{tabular}{|l|l|}
\hline Table Analyzed & Day 0 postoperative \\
\hline Column B & Without mesh \\
\hline vs. & vs. \\
\hline Column A & With mesh \\
\hline Unpaired t test & \\
\hline$P$ value & \\
\hline P value summary & $\ldots .$. \\
\hline Significantly different $(P<0.05) ?$ & Yes \\
\hline $\begin{array}{l}\text { One- or two-tailed } P \text { value? } \\
t, \text { df }\end{array}$ & Two-tailed \\
\hline How big is the difference? & $t=3.975$ df $=120$ \\
\hline Mean \pm SEM of column A & $1.313 \pm 0.0579, n=80$ \\
\hline Mean \pm SEM of column $B$ & $1.714 \pm 0.08544, n=42$ \\
\hline Difference between means & $0.4018 \pm 0.1011$ \\
\hline $95 \%$ confidence interval & 0.2017 to 0.6019 \\
\hline$R$ squared (eta squared) & \\
\hline$R$
\end{tabular}

Regarding the need for analgesic medication on the first postoperative day we also recorded a statistically significant difference between the two groups $(p=0.0506)$, the average need for analgesic medication being lower for group A compared to the group B. ( $3 \mathrm{~g}$ vs. $3.262 \mathrm{~g}$ ). The results are presented in table 2 .

The same statistically significant difference between the two groups was also recorded on the 2nd postoperative day. ( $p=0.0251)$ Also the need for analgesic medication was lower for group A. The results are presented in table 3.

of surgery compared to the rest of the days probably due to the persistence of the effects of anesthesia. The results

Table 1

STATISTICAL ANALYSIS OF THE DIFFERENCES BETWEEN THE TWO GROUPS ON THE DAY OF SURGERY 
Table 2

STATISTICAL ANALYSIS OF THE DIFFERENCES BETWEEN THE TWO GROUPS ON THE FIRST POSTOPERATIVE DAY

\begin{tabular}{|c|c|}
\hline Table Analyzed & Day 1 postoperative \\
\hline Column B & Without mesh \\
\hline vs. & vs. \\
\hline Column A & With mesh \\
\hline \multicolumn{2}{|l|}{ Unpaired $t$ test } \\
\hline$P$ value & 0.0506 \\
\hline$P$ value summary & ns \\
\hline Significantly different $(P<0.05)$ ? & No \\
\hline One- or two-tailed $\mathrm{P}$ value? & Two-tailed \\
\hline $\mathrm{t}, \mathrm{df}$ & $t=1.975 d f=120$ \\
\hline \multicolumn{2}{|l|}{ How big is the difference? } \\
\hline Mean \pm SEM of column A & $3 \pm 0, n=80$ \\
\hline Mean \pm SEM of column B & $3.262 \pm 0.1837, n=42$ \\
\hline Difference between means & $0.2619 \pm 0.1326$ \\
\hline $95 \%$ confidence interval & -0.0006554 to 0.5245 \\
\hline R squared (eta squared) & 0.03148 \\
\hline
\end{tabular}

Table 3

STATISTICAL ANALYSIS OF THE DIFFERENCES BETWEEN THE TWO GROUPS ON THE 2ND POSTOPERATIVE DAY

\begin{tabular}{|l|l|}
\hline Table Analyzed & Day 2 postoperative \\
\hline $\begin{array}{l}\text { Column B } \\
\text { vs. }\end{array}$ & Without mesh \\
\hline Column A & Ws. \\
\hline $\begin{array}{l}\text { Unpaired } t \text { test } \\
\text { P value }\end{array}$ & \\
\hline $\begin{array}{l}\text { P value summary } \\
\text { Significantly different }(P<0.05) ?\end{array}$ & Yes \\
\hline $\begin{array}{l}\text { One- or two-tailed } P \text { value? } \\
\text { t, df }\end{array}$ & Two-tailed \\
\hline $\begin{array}{l}\text { How big is the difference? } \\
\text { Mean } \pm \text { SEM of column A }\end{array}$ & 2.268 df $=120$ \\
\hline $\begin{array}{l}\text { Mean } \pm \text { SEM of column B } \\
\text { Difference between means }\end{array}$ & $3.262 \pm 0.1514, n=80$ \\
\hline $95 \%$ confidence interval & $0.5619 \pm 0.2478$ \\
\hline$R$ squared (eta squared) & 0.0713 to 1.053 \\
\hline
\end{tabular}

And on the 3rd postoperative day we recorded a statistically significant difference between the two groups $(p=0.0031)$. Also, for group $A$, the need for analgesic medication was lower compared to group $B$. The results are presented in table 4.

But on the 4th postoperative day, the results were not statistically different between the two groups $(p=0.1373)$. The results are presented in table 5 .

These results are probably due to the fact that in the case of group B, where no substitution material was used, the tension in the suture of the abdominal wall was higher, therefore the need for analgesic medication was higher in these patients compared to those to whom the surgical mesh was applied. Probably the longer the duration from surgery is, the greater the tension in the abdominal wall suture decreases, and therefore statistically significant differences have not been recorded since the 4th postoperative day.

Incisional hernias may lead to complications that could endanger the patient's life. The most common complications that may arise in these patients are the appearance of intestinal occlusion, strangulated incisional hernia, or intestinal necrosis. It has been found that even in asymptomatic patients, $10 \%$ of those will develop such
Table 4

STATISTICAL ANALYSIS OF DIFFERENCES BETWEEN THE TWO GROUPS ON THE 3RD POSTOPERATIVE DAY

\begin{tabular}{|l|l|}
\hline Table Analyzed & Day 3 postoperative \\
\hline Column B & Without mesh \\
\hline vs. & vs. \\
\hline Column A & With mesh \\
\hline Unpaired $t$ test & \\
\hline $\begin{array}{l}\text { P value } \\
\text { P value summary }\end{array}$ & $\ldots$ \\
\hline Significantly different $(P<0.05) ?$ & Yes \\
\hline One- or two-tailed $P$ value? & Two-tailed \\
\hline$t$, df & $t=3.018 d f=120$ \\
\hline How big is the difference? & \\
\hline Mean \pm SEM of column A & $2.313 \pm 0.1802, n=80$ \\
\hline Mean \pm SEM of column B & $3.19 \pm 0.208, n=42$ \\
\hline Difference between means & $0.878 \pm 0.2909$ \\
\hline $95 \%$ confidence interval & 0.302 to 1.454 \\
\hline$R$ squared (eta squared) & \\
\hline
\end{tabular}

Table 5

STATISTICAL ANALYSIS OF DIFFERENCES BETWEEN THE TWO BATCHES ON THE 4TH POSTOPERATIVE DAY

\begin{tabular}{|l|l|}
\hline Table Analyzed & Day 4 postoperative \\
\hline Column B & Without mesh \\
\hline vs. & vs. \\
\hline Column A & With mesh \\
\hline & \\
\hline Unpaired t test & \\
\hline P value & $n s$ \\
\hline P value summary & No \\
\hline Significantly different $(P<0.05) ?$ & Two-tailed \\
\hline One- or two-tailed $P$ value? & $\mathrm{t}=1.496 \mathrm{df}=120$ \\
\hline $\mathrm{t}, \mathrm{df}$ & \\
\hline & \\
\hline How big is the difference? & $1.813 \pm 0.1716, \mathrm{n}=80$ \\
\hline Mean \pm SEM of column A & $2.262 \pm 0.2552, \mathrm{n}=42$ \\
\hline Mean \pm SEM of column B & $0.4494 \pm 0.3004$ \\
\hline Difference between means & -0.1454 to 1.044 \\
\hline $95 \%$ confidence interval & \\
\hline R squared (eta squared) & \\
\hline
\end{tabular}

complications if the surgical treatment of the incisional hernia is not performed [6]. Therefore, the operative indication in these patients is absolute.

Currently, in surgical practice there are several technical variants used in the surgical treatment of incisional hernias. Classically, there are two types of surgical treatments in these patients: surgical procedures using heterologous materials (surgical meshes) and surgical procedures that do not use heterologous materials [ 7].

In the last period due to the appearance on the market of surgical meshes that have a very good tissue integration, given that the relapse rate is lower in the cases where prosthetic materials are used in these patients, most of the authors recommend the use of surgical meshes in the surgical treatment of patients with incisional hernias. The most common type of surgical mesh used in these patients is the polypropylene mesh. This type of mesh, in addition to having a very good tissue integration, also has the advantage of being cheap and easy to use. Currently, the polypropylene mesh is used in general surgery as well as 
in thoracic surgery or obstetrics and gynaecology $[8,9]$. There are discussions in the literature regarding the placement of surgical meshes in patients with incisional hernias. Classically, the mesh may be located over the aponeurosis, properitoneal or intraperitoneal.

Although the use of surgical meshes can reduce the recurrence of the incisional hernias, in the long run, due to the use of prosthetic materials, different types of postoperative complications such as chronic pain, abdominal wall infections or entero-cutaneous fistulas may occur. These postoperative complications over time may obscure the prognosis of these patients $[10,11]$.

Regarding the surgical approach used in patients with incisional hernias, more and more centers in the world have been using the laparoscopic or robotic approach. The advantages of these techniques are that they provide lower postoperative morbidity and mortality compared to the classic approach, a lower level of postoperative pain, and provide a faster social reintegration of these patients. The major disadvantage is the very high price of materials used in these surgeries $[12,13]$.

A particularly important part of postoperative treatment in patients with incisional hernias is the treatment of pain. It is currently known that the main local postoperative complications that may occur in these patients are local seromas, abdominal wall infections and postoperative pain $[14,15]$. In the vast majority of cases, the usual analgesics are sufficient for the relief of postoperative pain, usually the use of opioid analgesics is not necessary, the latter having significant adverse effects [16,17]. Usually, analgesic medication is administered to these patients by general (intramuscular or intravenous) until resumption of intestinal transit, and then analgesic drugs can be administered orally. There are in literature, authors that recommend the local administration of local anesthetics to relieve pain in these patients $[18,19]$.

The importance of treating postoperative pain in patients with incisional hernias was highlighted by many authors, there are cited cases in the literature of patients who were readmitted after discharge due to postoperative pain. [20] The main causes thatcan trigger severe postoperative pain in these patients may be the suturing of nerves during reconstruction of the abdominal wall or fixation of the surgical mesh, or due to small areas of abdominal wall necrosis [21,22]. Another cause of postoperative pain may be the presence of seromas in the abdominal wall [23]. In some cases, postoperative pain can be extremely severe, can become chronic in time, difficult to treat. In these cases the mesh can even be extracted [24].

Regarding the incidence of postoperative pain, studies published in the literature have shown contradictory results, if there are authors who maintain that there are no differences in the incidence of postoperative pain between different surgical techniques, there are authors who support the contrary, which we have also proven in our study. Usually, postoperative pain treated with the usual analgesic medication (minor analgesics, non-steroidal antiinflammatory drugs) should improve within 6 weeks. $[25,26]$ The persistence of pain over 6 weeks is usually due to a local seroma, local hematoma, mesh migration, or the existence of intraperitoneal adherence $[27,28]$.

\section{Conclusions}

Our study has shown that, when using the polypropylene mesh in the surgical treatment of incisional hernias, the need for analgesic medication is lower in the immediate postoperative period compared to cases where surgical meshes are not used in the surgical treatment of such patients.

\section{References}

1.SANDERS DL, KINGSNORTH AN., BMJ ., 344,2012, e2843.

2.SUGERMAN HJ ., KELLUM JMJR., REINESHD., DEMARIA EJ ., NEWSOME HH., LOWRY JW., Am. J. Surg., 171,1996,nr.1,p.80-84

3.HESSELINK VJ ., LUIJ ENDIJ K RW., DE WILT J H., HEIDE R., J EEKEL J ., Surg. Gynecol. Obstet., 176,1993,nr.3,p.228-234

4.SUCIU BA., HALMACIU I., VUNVULEA V., BRINZANIUC K., Eur. J. Cardiothorac. Surg., 53,2018,nr.4,p.895-896

5.WARREN JA., LOVE M., Surg. Clin. North. Am., 98,2018,nr.3,p.537559

6.HELGSTRAND F., Dan. Med. J., 63,2016,nr.7,pii: B5258.

7.MURESAN, M., MURESAN, S., BARA, T., BRINZANIUC, K., SALA, D., SUCIU B., RADU N., Ann. Ital. Chir., 86,2015,p.421-426

8.SUCIU BA., HALMACIU I., BUD V., COPOTOIU C., FODOR D., TRAMBITAS C., GODJA D., VUNVULEA V., MOLNAR C., BRINZANIUC K., Mat. Plast. 54,2017,no.4,p.626-629

9.SUCIU, BA., HALMACIU, I., BUD, V., COPOTOIU, C., FODOR, DRP., TRAMBITAS, C., VUNVULEA, V., MOLNAR, C., BRINZANIUC, K., Mat. Plast. 54,2017,no.3, p.520-522

10.DIETZ UA., MENZELS., LOCK J., WIEGERING A., Dtsch. Arztebl. Int., 115,2018,nr.3,p.31-37

11.CANTON SA., PASQUALI C., Updates. Surg., 69,2017,nr.4,p.479-483 12.ORTHOPOULOS G., KUDSI OY., J. Laparoendosc. Adv. Surg. Tech. A., 28,2018,nr.4,p.434-438

13.SANCHEZ A., RODRIGUEZ O., JARA G., SANCHEZ R., VEGAS L., ROSCIANO J., ESTRADA L., J. Robot. Surg., 12,2018,nr.3,p.523-527

14.BEDI AP., BHATTI T., AMIN A., ZUBERI J., J. Minim. Access. Surg., 3,2007,nr.3,p.83-90

15. SUCIU BA., PAP Z., DENES L., BRINZANIUC K., COPOTOIU C., PAVAI Z., Rom. J. Morphol. Embryol., 57,2016,nr.2,p.495-500.

16.SUCIU BA., GURZU S., MARGINEAN L., MILUTIN D., HALMACIU I., JUNG I., BRANZANIUC K., MOLNAR C., Medicine (Baltimore). 94, 2015, nr.42, e1848.

17.TRAMBITAS, C., POP, TS., TRAMBITAS MIRON, AD., DOROBANTU, DC., BRINZNIUC, K., Rev. Chim.(Bucharest), 68,2017,no.2,p.387-389 18.GHERGHINESCU MC., COPOTOIU C., LAZAR AE., POPA D., MOGOANTA SS., MOLNAR C., Hernia., 21,2017,nr.5,p.677-685 19.BUD V., SUCIU BA., BUTIURCA V., BRINZANIUC K., COPOTOIU R., COPOTOIU C..., SIN A., Rom. J. Morphol. Embryol., 54,2013,nr.1,p.115119.

20.MORENO-EGEA A., CASTILLO JA., GIRELA E., CANTERAS M., AGUAYO JL., Surg. Laparosc. Endosc. Percutan. Tech., 12,2002, nr.3,p.171-174.

21.BAGEACU S., BLANC P., BRETON C., GONZALES M., PORCHERON J., CHABERT M., BALIQUE J ., Surg. Endosc., 16,2002,nr.2,p.345-348 22.PERKER HH 3rd., NOTTINGHAM JM., BYNOE RP., YOST MJ., Am. Surg., 68,2002,nr.6,p.530-533

23.AURA T., HABIB E., MEKKAOUI M., BRASSIER D., ELHADAD A., J. Laparoendosc. Adv. Surg. Tech. A., 12,2002,nr.4,p.263-267

24.KUA KB., COLEMAN M., MARTIN I., O'ROURKE N., ANZ. J. Surg., 72,2002,nr4,p.296-299.

25.ITANI KM., HUR K., KIM LT., ANTHONY T., BERGER DH., REDA D., NEUMAYER L., Arch. Surg., 145,2010,nr.4,p.322-328

26.SAJID MS., BOKHARI SA., MALLICK AS., CHEEK E., BAIG MK., Am J Surg. 197,2009,nr.1,p.64-72

27.PALANIVELU C., JANI KV., SENTHILNATHAN P., PARTHASARATHI R., MADHANKUMAR MV., MALLADI VK., Hernia., 11,2007,nr.3,p.223-228 28.CARBONELL AM., CRISS CN., COBB WS., NOVITSKY YW., ROSEN MJ ., J Am. Coll. Surg., 217,2013,nr.6,p.:991-998

Manuscript received: 3.08 .2018 